International Journal of Advanced Academic Research (Arts, Humanities and Education) | ISSN: 2488-9849

Vol. 6, Issue 12 (December, 2020)|www.ijaar.org

Journal DOI: 10.46654/ij.24889849

Article DOI: 10.46654/ij.24889849.a61252

\title{
SCHOOL MONITORING AND MANAGEMENT EFFECTIVENESS OF PUBLIC SECONDARY SCHOOLS AMONG GOVERNING BOARDS IN OYO STATE, NIGERIA
}

\author{
${ }^{1}$ AKINWUMI Femi Sunday (Ph.D.) \\ 08033246448 \\ femaking@yahoo.com
}

And

${ }^{2}$ OPADEYE, Oluyemi Bolanle

08061395539

yemijire@gmail.com

${ }^{1,2}$ Department of Educational Management

University of Ibadan, Ibadan Nigeria

\begin{abstract}
It has been observed that management of Public Secondary Schools (PSSs) usually requests and waits for funds and other resources from either the state or federal government for effective running of the public schools. This has brought about ineffectiveness of public schools due to long waiting of resources. However, studies have been conducted on Management Effectiveness $(M E)$ with other variables but none of these studies were able to consider school monitoring in relation to ME. Based on this, the study investigated school monitoring as a major correlate of management effectiveness among governing boards of public secondary schools in Oyo State, Nigeria using correlational survey design. Population of this study comprised 5,643 members of School Governing Boards (SGBs) in 627 rural and urban PSSs in Oyo State. A total of 1585 SGBs members was selected using systematic random sampling. Data obtained through selfconstructed questionnaire was subjected to quantitative analysis using frequency count, percentage and independent t-test at 0.05 level of significance. The study revealed that state of ME (human, financial and material resources) was found to be low in PSSs. Level of PSSs monitored by SGBs in Oyo State, Nigeria was considered to be high. School location has significant effect on ME and school monitoring system. Appropriate monitoring system should be ensured to effectively manage the available human, financial and material resources in PSSs by the school governing boards that would create significant impetus on the quality of the public secondary school system in Oyo State, Nigeria.
\end{abstract}

Keywords: School Monitoring, Management Effectiveness, SGB, Public Secondary Schools 


\section{Introduction}

The issue of management effectiveness of public secondary schools in Oyo State to achieve the desired objectives has always been of great concern to education stakeholders in the state particularly policy makers, educational administrators, teachers, parents and the state government that funds education. Management effectiveness of public secondary schools appears to be low. This could be seen among other areas in the aspect of student's performance in Senior Secondary Certificate Examination (SSCE) which had been consistently poor over the years compared to other states in Nigeria. Kalagbor (2016) submitted that the state of public secondary school has become worrisome, to the extent that many secondary students perform poorly in external examinations. Oladeji (2017) was of the opinion that poor performance of public secondary school students in the SSCE conducted by West African Examination Council (WAEC) in the last three years called for an urgent attention. Hence,the poor performance of public secondary school students shows level of management effectiveness of public secondary school among school governing board in Oyo state.

Hence, effectiveness is crucial for the success of public secondary school because it measures the level of accomplishment in the area of stated goals, objectives and available inputs. Thus, effectiveness deals with ends and achievement of goals. Schools effectiveness requires effective school management that is assisted by the relevant stakeholders in the education sector. such as school administrators, teachers, Parents Teacher Association, students, school governing boards among others. However, the school governing boards is the key figure in the management of school. Therefore the importance of the school governing boards to enhance management effectiveness of public secondary school cannot be overlooked. The extent to which the boards coordinate and direct the resources- finance, human and material of the school goes a long way to determine the effectiveness of public secondary schools. However, it seems that all these resources are not in good shape for effective teaching and learning to take place. This could lead to an ineffective management of public secondary schools among governing boards in the state.

The School Governing Boards (SGBs), as the major agent in the promotion of school effectiveness, the boards are expected to maintain the quality of output, educational resources and infrastructural facilities in public secondary schools. Daily, Dalton and Cannella (2003) stated that school monitoring; service; strategy and resource provision are the expected role to be performed by SGBs. The board is also expected to promote the best interests of the school, to strive and ensure its development through the provision of quality education. The board is to stand in a position of trust towards the school, should be able to act in good faith and not engage in any unlawful conduct that may affect the interests of the school (Galetuke, 2017). This implies that all SGB members should be able to synergise their operative efforts towards the effective management in the area of academic performance and quality education ofstudents.

In the light of this, management effectiveness of school could be expressed as the ability of school managers to utilize available resources which include human, financial and material resources at a maximal result. Management effectiveness describes obtaining a maximum output with less input- human, financial and material (Ozkan and Tokel, 2018). Management effectiveness could only manifest where SGBs is able to plan, organize, co-ordinate, direct and 
control the available resources of school system to achieve the goals and objectives of the public secondary schools. Ikghusi and Theanacho (2016) and Nwakpa (2017) identified poor finance, inadequate provision of infrastructure, curriculum problem, community interference and low quality of teachers as the challenges confronting the management of school education. The researcher stressed that, all efforts to cushion these challenges towards achieving educational goals and objectives seem to be abortive as a result of perceived ineffective management of public secondary schools in Oyo State.

School management generally involves planning, organising, budgeting, staffing, directing and coordinating of human, material and financial resources in a school towards the realization of educational goals and objectives. The human resources which include the staff are the fulcrum on which the educational system rests and has great impetus on the quality of educational output (Fadipe, 2003; Achimugu, 2005 and Omiunu, 2014). The material resources include the infrastructure, building, chairs and tables, sports complex, farms and gardens including trees, roads and paths, among others. Material resources play pivotal role in the actualization of the educational goals and objectives through the staff and students, hence the need for infrastructural management.

According to Ogie (2015), the provision of material resources involves the proper usage, storage and maximum security provision to ensure the facilities available are well used and kept after use. Infrastructural management and other school facilities management in secondary schools are seen as an integral part of the overall administration of the school. According to Uchendu (2011), adequate supply of material resources could facilitate effective teaching and learning in secondary schools. This would invariably enhance management effectiveness in public secondary school. The financial management includes the availability of funds to effectively manage the human and the material resources. Moja (2000) and Omorege (2005) observed that, there are limited financial resources in the Nigeria education system which has led to high degree of low performance of students. All these resources are expected to be in place and effectively managed by educational stakeholders concerned in the state if overall performance of the students in external examinations is to be achieved.

There have been several factors that influence management effectiveness in secondary school system. These include government and political issues, teachers' issues, school head and leadership issues, students' issues, family issues, school location among others (Kotirde and Yunos, 2015). Meanwhile, the lack of monitoring of schools hasalso been observed as major challenges affecting the public secondary schools in Nigeria (Edho 2009). The researcher added that school monitoring in Nigerian public secondary schools is very weak. Hence, there is need for regular monitoring of schools (Ayeni, 2012; Aja, Eze and Nick, 2014). This implies that influence of school monitoring on management effectiveness cannot be overemphasized.

Monitoring could be referred to as the continuous assessment of school activities and implementation of relevant programmes that are directed to enhance the smooth running of the school system with the use of human resources, material resources and financial inputs (Mertens, 2005). Monitoring in school system could also mean the process by which information is being gathered with respect to human, finance and material resource. Public secondary school is 
expected to be monitored by SGBs in order to improve academic performance of students. School monitoring could therefore be done by SGBs set up by government so as to minimize mass failure of students in external examination. Marriott and Goyder (2009) stated that effective school monitoring provides information about the picture of performance at all levels to the management team, and ultimately the governing body, which could help facilitate decisionmaking and learning in the school system. Monitoring of human, finance and material resources of public secondary school could be of help to reshape teaching and learning in the state. Mncube, Harber, and Du Plessis (2011) submitted that school monitoring of teaching and learning could assist school governing board to know about the needs of the learners, teachers and school principal. Kotirde and Yunos (2015) expressed that a system that is not monitored could collapse. This could lead to gross negligence of academic activities, low performance, lack of schools discipline and disobedience to school rules and regulations.

Kotirde and Yunos (2015) noted that success of any school administrator largely depends on monitoring and supervision placed on the human, material and financial resources made available for the school. However, they added that the present situation of schools monitoring has not been encouraging as there have been evidences of the lack of monitoring of personnel and instructional materials. Hence, this has led to failures in several public secondary schools in Nigeria. However, the mode of running the public and private school in Nigeria differs and poses different challenges. For instance, management of public secondary schools would have to request and wait for funds and other resources from either the state or federal government for effective running of the public schools (Chen, 2019). During the long waiting for funding from government could lead to ineffectiveness of public schools.

Aside this, school location either in the rural or urban has significant effect on the management effectiveness of public secondary school. Mulkeen (2005) submitted that monitoring of teachers could be difficult in rural areas than that of urban. This could be due to the fact that member of school governing boards usually go to urban office to make administrative arrangements and therefore stay away longer from school. This type of absence by members of school governing boards in rural school could jeopardize management effectiveness. Likewise, schools in remote area are not likely to be visited by members of school governing boards due to far distance from urban area. If this is persistent in public secondary school, management effectiveness may not be achieved. Frame (1990) affirmed that school location has significant effect on the discipline, performance of teachers and students, philosophy, tradition and perspective. Ekpoh and Bassey (2011) concluded that school location influences principals' management of indiscipline. This has called for attention and the need to focus on Nigeria public education school system. Hence, this study investigated school monitoring and management effectiveness among school governing boards in public secondary schools in Oyo State, Nigeria.

\section{Purpose of the Study}


The main purpose of this study was to investigate the relationship between schools monitoring and management effectiveness among school governing boards in public secondary schools in Oyo State, Nigeria. Specifically, the paper examined the state of management effectiveness of public secondary schools and level of public secondary schools monitored by SGBs in Oyo State, Nigeria.

\section{Research Questions}

The following research questions were used to drive the study:

1. What is the state of management effectiveness (human, financial and material resources) in public secondary schools in Oyo State, Nigeria?

2. What is the level of public secondary schools monitoring by SGBs in Oyo State, Nigeria?

\section{Hypotheses}

The following hypotheses were formulated and tested at 0.05 level of significance

$\mathbf{H}_{01}$ : There is no significant difference in management effectiveness between SGBs of urban and rural public secondary schools in Oyo State, Nigeria

$\mathbf{H}_{\mathbf{0 2}}$ : There is no significant difference in school monitoring between SGBs of urban and rural public secondary schools in Oyo State, Nigeria

\section{Methodology}

The study adopted correlational survey design and focused on SGBs in Oyo State, Nigeria. The population of this study comprised 5,643 members of SGBs in 627 public secondary schools in rural and urban areas of Oyo State. This information is presented in Table 1.

Table 1: Total Population of School Governing Board Members (SGBM)in Public Secondary Schools in Oyo State across Zones

\begin{tabular}{|c|c|c|c|c|c|c|}
\hline \multirow[t]{2}{*}{$\mathrm{S} / \mathrm{N}$} & \multirow[t]{2}{*}{ Zones } & \multicolumn{2}{|c|}{$\begin{array}{l}\text { Total number of schools per } \\
\text { location }\end{array}$} & \multirow{2}{*}{$\begin{array}{c}\text { Total } \\
\text { number of } \\
\text { schools per } \\
\text { zone }\end{array}$} & \multirow{2}{*}{$\begin{array}{c}\text { Total } \\
\text { number of } \\
\text { SGBM per } \\
\text { School }\end{array}$} & \multirow{2}{*}{$\begin{array}{l}\text { Total number of } \\
\text { SGBM per zone }\end{array}$} \\
\hline & & Urban & Rural & & & \\
\hline 1 & Oyo Zone & 66 & 23 & 89 & 9 & 801 \\
\hline 2 & Ibadan Zone 1 & 165 & - & 165 & 9 & 1485 \\
\hline 3 & Ibadan Zone II & 78 & 73 & 151 & 9 & 1359 \\
\hline 4 & Eruwa Zone & 23 & 28 & 51 & 9 & 459 \\
\hline 5 & Ogbomoso Zone & 31 & 53 & 84 & 9 & 756 \\
\hline 6 & Saki Zone & 28 & 59 & 87 & 9 & 783 \\
\hline & TOTAL & 391 & 236 & 627 & & 5,643 \\
\hline
\end{tabular}


The information in Table1 shows that there are six political zones in Oyo State hence, a multistage sampling procedure was adopted to select respondents for this study. In the first stage, stratified sampling technique was used to select $50 \%$ of the schools from each zone across the rural and urban schools, giving a total of 316 schools. At the second stage, systematic random sampling was employed to select every first member of the lists of the school governing board members totaling 1585 SGB members in Oyo State, Nigeria. Detail is presented in Table 2.

\section{Table 2: Sample size and Technique}

\begin{tabular}{|c|c|c|c|c|c|c|c|c|c|c|}
\hline \multirow[t]{2}{*}{$\mathrm{S} / \mathrm{N}$} & \multirow[t]{2}{*}{ Zones } & \multicolumn{4}{|c|}{$\begin{array}{l}\text { No of selected schools } \\
\text { per location }\end{array}$} & \multicolumn{2}{|c|}{$\begin{array}{l}\text { No of selected } \\
\text { schools per zone }\end{array}$} & \multicolumn{2}{|c|}{$\begin{array}{l}\text { Members of SGBM selected } \\
\text { in each school per zone }\end{array}$} & \multirow{2}{*}{$\begin{array}{l}\text { Total no } \\
\text { selected }\end{array}$} \\
\hline & & $\begin{array}{l}\text { Total } \\
50 \%\end{array}$ & $50 \%$ & Tot: & & Total & $50 \%$ & Total & $50 \%$ & \\
\hline 1 & Oyo Zone & 66 & 33 & 23 & 12 & 89 & 45 & 9 & 5 & 225 \\
\hline 2 & $\begin{array}{l}\text { Ibadan Zone } \\
1\end{array}$ & 165 & 83 & - & - & 165 & 83 & 9 & 5 & 415 \\
\hline 3 & $\begin{array}{l}\text { Ibadan Zone } \\
\text { II (Moniya) }\end{array}$ & 78 & 39 & 73 & 37 & 151 & 76 & 9 & 5 & 380 \\
\hline 4 & Eruwa Zone & 23 & 12 & 28 & 14 & 51 & 26 & 9 & 5 & 130 \\
\hline 5 & $\begin{array}{l}\text { Ogbomoso } \\
\text { Zone }\end{array}$ & 31 & 16 & 53 & 27 & 84 & 43 & 9 & 5 & 215 \\
\hline 6 & Saki Zone & 28 & 14 & 59 & 30 & 87 & 44 & 9 & 5 & 220 \\
\hline & TOTAL & 391 & 196 & 236 & 120 & 627 & 316 & & & 1585 \\
\hline
\end{tabular}

Data on variables of interest in this study was obtained through self-developed questionnaire. Items in the questionnaire for the school monitoring and management effectiveness were captured through a four likert scale method using agree, strongly agree, disagree and strongly disagree where a respondent would be allowed to tick one where applicable. To ensure that the psychometric properties of the instrument are guaranteed, 20 copies of questionnaire are administered to SGB members that are not part of the sample size of this study and the information obtained was subjected to reliability analysis using the Cronbach alpha. The result yielded Cronbach Alpha coefficients of 0.86 and 0.89 for school monitoring and management effectiveness respectively. This shows that the instrument was highly reliable. Descriptive statistics of frequency and percentage were used to answer research questions while inferential statistics of Pearson Product Moment Coefficient and independent T-test were employed to test hypotheses formulated for the study. 


\section{Results}

Research Question 1: what is the state of management effectiveness (human, financial and material resources) in public secondary in Oyo State, Nigeria?

\section{Table 3: State of Management Effectiveness in the area of Human Resource}

Strongly Disagree
Disagree

Adequate numbers of teachers are in the Agree schools on various subjects.

Strongly Agree
No indication

Total

Strongly Disagree

Teachers' welfare is being taken care of, Disagree which motivate them for high level commitment to duty.

Agree

Strongly Agree

No indication
Total

Strongly Disagree

Disagree

Most teachers in the school have pre-requisite Agree qualifications for the job

\section{Strongly Agree}

No indication

Total

Strongly Disagree

There have been various in-service training Disagree

programme for the teachers to enhancing their service delivery.

Agree

Strongly Agree

No indication
Total

Strongly Disagree

Disagree

Staff promotions are effected as and when due Agree

by the government.

Strongly Agree
Frequency

No indication

Total

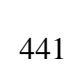

Percent

333

756

9

27

1566

423

1062

9

27

45

1566

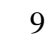

135

153

1260

9

1566

234

99

801

198

234

1566

567

576

243

162

28.2

21.3

48.3

.6

1.7

100.0

27.0

67.8

.6

1.7

2.9

100.0

.6

8.6

9.8

80.5

.6

100.0

14.9

6.3

51.1

12.6

14.9

100.0

36.2

36.8

15.5

10.3

1.1

1566

100.0

The result in Table 3 reveals that a higher percentage (90\%) confirmed that most teachers in the school have the necessary and pre-requisite qualifications that are needed for their teaching job. Also, 64\% affirmed that various in-service training programme have been organized for the teachers in the school that would enhance their service delivery. Also, few (49\%) attested that there are adequate numbers of teachers that could effectively cater for various subjects in the schools. In addition, very few (26\%) stated that staff promotions are done at the right time when due by the government. Moreover, only very few (2\%) confirmed that the welfare of teachers is being taken care of, which motivate them for high level of commitment to duty. Juxtaposing the 
Journal DOI: 10.46654/ij.24889849

Article DOI: 10.46654/ij.24889849.a61252

information together, it implies that there is an ineffective management in the area of human resource in public secondary schools in Oyo State, Nigeria.

\section{Table 4: State of Management Effectiveness in term of Financial Resource}

\begin{tabular}{|c|c|c|c|}
\hline & & Frequency & Percent \\
\hline \multirow{6}{*}{$\begin{array}{l}\text { There are financial availability to cater for } \\
\text { leave allowances of staff as and when due by } \\
\text { the government }\end{array}$} & Strongly Disagree & 306 & 19.5 \\
\hline & Disagree & 468 & 29.9 \\
\hline & Agree & 558 & 35.6 \\
\hline & Strongly Agree & 153 & 9.8 \\
\hline & No indication & 81 & 5.2 \\
\hline & Total & 1566 & 100.0 \\
\hline \multirow{6}{*}{$\begin{array}{l}\text { There are financial availability to cater for the } \\
\text { provision of needed educational resources by } \\
\text { the government }\end{array}$} & Strongly Disagree & 189 & 12.1 \\
\hline & Disagree & 243 & 15.5 \\
\hline & Agree & 666 & 42.5 \\
\hline & Strongly Agree & 369 & 23.6 \\
\hline & No indication & 99 & 6.3 \\
\hline & Total & 1566 & 100.0 \\
\hline \multirow{6}{*}{$\begin{array}{l}\text { There are financial resources available for the } \\
\text { provision of teaching-learning resources to } \\
\text { schools by the government }\end{array}$} & Strongly Disagree & 378 & 24.1 \\
\hline & Disagree & 585 & 37.4 \\
\hline & Agree & 459 & 29.3 \\
\hline & Strongly Agree & 126 & 8.0 \\
\hline & No indication & 18 & 1.1 \\
\hline & Total & 1566 & 100.0 \\
\hline \multirow{6}{*}{$\begin{array}{l}\text { There are financial resources to maintain } \\
\text { needed infrastructure by the government }\end{array}$} & Strongly Disagree & 387 & 24.7 \\
\hline & Disagree & 387 & 24.7 \\
\hline & Agree & 567 & 36.2 \\
\hline & Strongly Agree & 198 & 12.6 \\
\hline & No indication & 27 & 1.7 \\
\hline & Total & 1566 & 100.0 \\
\hline
\end{tabular}

The information in Table 4 reveals that a higher percentage (66\%) confirmed that financial resources are made available to meet the needed educational resources by the government to the schools. Also, few (45\%) stated that financial resources are made available to cater for leave allowances of staff as and when due by the government. In addition, few (49\%) stated that financial resources are made available by the government to maintain needed infrastructure. Moreover, very few (37\%) of the respondents stated that financial resources are made available by the government for the provision of teaching-learning resources to schools. The information provided shows that the provision of financial resource is considered to be low hence poor financial management among school governing board members.

Table 5: State of Management Effectiveness in the area of Material Resource

Teachers make regular improvisation of teaching - aids for an effective teaching to take place
Frequency

Percent

Strongly Disagree
Disagree
Agree
Strongly Agree
No indication
Total

100.0 


\begin{tabular}{|c|c|c|c|}
\hline \multirow{6}{*}{$\begin{array}{l}\text { There are enough infrastructures in the } \\
\text { schools such as classrooms for effective } \\
\text { teaching-learning process }\end{array}$} & Strongly Disagree & 468 & 29.9 \\
\hline & Disagree & 513 & 32.8 \\
\hline & Agree & 396 & 25.3 \\
\hline & Strongly Agree & 171 & 10.9 \\
\hline & No indication & 18 & 1.1 \\
\hline & Total & 1566 & 100.0 \\
\hline \multirow{6}{*}{$\begin{array}{l}\text { There is proper maintenance of the available } \\
\text { teaching-learning resources in the school }\end{array}$} & Strongly Disagree & 225 & 14.4 \\
\hline & Disagree & 459 & 29.3 \\
\hline & Agree & 594 & 37.9 \\
\hline & Strongly Agree & 261 & 16.7 \\
\hline & No indication & 27 & 1.7 \\
\hline & Total & 1566 & 100.0 \\
\hline
\end{tabular}

The result in Table 5 reveals that approximately average (59\%) of the respondents stated that teachers make regular improvisation of teaching aids for an effective teaching to take place. Also, 54\% stated that there is proper maintenance of the available teaching-learning resources in the school. In addition, very few (36\%) of the respondents confirmed that there are enough infrastructures in the schools such as classrooms for effective teaching-learning process. The information provided with regards to the material resource management depicts that there is an ineffective management in term of material resource among school governing board members in Oyo State, Nigeria. Based on tables 3, 4 and 5, the result reveals that management effectiveness in the area of human, financial and material resources was found to be ineffective which can be interpreted as low in public secondary schools in Oyo State, Nigeria. This supports the works of Moja (2000) and Omorege (2005) that there are evidences of poor management of public secondary schools in Oyo State, Nigeria.

The result is also in line with the statement made by Fadipe (2003); Achimugu (2005) and Omiunu (2014) that, the human resources of the education system are the fulcrum on which the educational system is built which could further have great impetus on the quality of educational output, it would be important to call attention to the fact that such inefficiency as observed in this study could pose a significant influence on the quality of the secondary education system in Nigeria.

The finding of this study is equally agreed with the observation made by Uchendu (2011) who stated that the adequate supply of material resources which is a part of the management effectiveness could facilitate teaching and learning in the public secondary school hence, it deems fit to note that the material resource inefficiency as observed in this study could pose an influence on the efficiency of teaching and learning in the public secondary in Oyo State, Nigeria. Also, the findings of this study concur with the work of Moja (2000) and Omorege (2005) that there are limited financial resources in the Nigeria education system which could pose significant effect on the performance in the public secondary schools in Oyo State, Nigeria.

Research Question 2: what is the level of public secondary schools monitoring by school governing boards in Oyo State, Nigeria? 
International Journal of Advanced Academic Research (Arts, Humanities and Education) | ISSN: 2488-9849 Vol. 6, Issue 12 (December, 2020) | www.ijaar.org

Journal DOI: 10.46654/ij.24889849

Article DOI: 10.46654/ij.24889849.a61252 
Table 6: Level of School Monitoring by School Governing Boards

\begin{tabular}{|c|c|c|c|}
\hline & & Frequency & Percent \\
\hline \multirow{7}{*}{$\begin{array}{l}\text { There is adequate monitoring of } \\
\text { teachers'/students' progress to ensure the } \\
\text { compliance with the set rules and regulations. }\end{array}$} & Strongly Disagree & 99 & 6.3 \\
\hline & Disagree & 54 & 3.4 \\
\hline & Agree & 738 & 47.1 \\
\hline & Strongly Agree & 603 & 38.5 \\
\hline & No indication & 72 & 4.6 \\
\hline & Total & 1566 & 100.0 \\
\hline & Strongly Disagree & 36 & 2.3 \\
\hline \multirow{5}{*}{$\begin{array}{l}\text { Adequate school monitoring is ensured to present } \\
\text { new ideas to the teachers and students in some } \\
\text { confused areas. }\end{array}$} & Disagree & 117 & 7.5 \\
\hline & Agree & 864 & 55.2 \\
\hline & Strongly Agree & 459 & 29.3 \\
\hline & No indication & 90 & 5.7 \\
\hline & Total & 1566 & 100.0 \\
\hline \multirow{6}{*}{$\begin{array}{l}\text { Routine monitoring in my school is done to know } \\
\text { whether the expected changes on corrected } \\
\text { mistakes/errors are being effected for improvement }\end{array}$} & Strongly Disagree & 72 & 4.6 \\
\hline & Disagree & 90 & 5.7 \\
\hline & Agree & 783 & 50.0 \\
\hline & Strongly Agree & 513 & 32.8 \\
\hline & No indication & 108 & 6.9 \\
\hline & Total & 1566 & 100.0 \\
\hline \multirow{6}{*}{$\begin{array}{l}\text { There is adequate school monitoring to allow } \\
\text { School Governing Board members know the } \\
\text { progression of the students and some of the } \\
\text { challenges they face }\end{array}$} & Strongly Disagree & 36 & 2.3 \\
\hline & Disagree & 117 & 7.5 \\
\hline & Agree & 729 & 46.6 \\
\hline & Strongly Agree & 576 & 36.8 \\
\hline & No indication & 108 & 6.9 \\
\hline & Total & 1566 & 100.0 \\
\hline \multirow{6}{*}{$\begin{array}{l}\text { School monitoring is used as an instrument to } \\
\text { identifying the professional development needs of } \\
\text { teachers }\end{array}$} & Strongly Disagree & 90 & 5.7 \\
\hline & Disagree & 54 & 3.4 \\
\hline & Agree & 693 & 44.3 \\
\hline & Strongly Agree & 630 & 40.2 \\
\hline & No indication & 99 & 6.3 \\
\hline & Total & 1566 & 100.0 \\
\hline
\end{tabular}

The result in Table 6 reveals that $86 \%$ stated that there is adequate monitoring of teachers'/students' progress to ensure the compliance with the set rules and regulations. Also, $85 \%$ noted that adequate school monitoring is ensured to present new ideas to the teachers and students in some confused areas. In addition, $83 \%$ stated that routine monitoring in my school is done to know whether the expected changes on corrected mistakes/errors are being effected for improvement. The result in Table 6 also reveals that $83 \%$ stated that there is adequate school monitoring to allow School Governing Board members know the progression of the students and some of the challenges they face. Moreover, $85 \%$ stated that school monitoring is used as an instrument to identifying the professional development needs of teachers. Based on these findings, it shows that level of public secondary schools monitored by school governing boards in Oyo State, Nigeria is high. This implies that there are adequate and necessary school 
monitoring process put in place by school monitoring board to ensure school effectiveness in secondary schools in Oyo State, Nigeria. The finding of this study is consistent with the result of Owoeye (1999); Moja (2000); Mertens (2005); Marriott and Goyder (2009); Edho (2009); Ayeni (2012); Aja, Eze and Nick (2014); Kotirde and Yunos (2015); among others that school monitoring is a major factor that influence management effectiveness in school system. However, the result contradicts with the submission of Moja (2000) and Edho (2009) that there are evidences of weak school monitoring processes in public secondary schools in Oyo State, Nigeria.

Hypothesis 1: There is no significant difference in management effectiveness between school governing boards of urban and rural public secondary schools in Oyo State, Nigeria

Table 7: Independent t-test Comparison of Management Effectiveness

\begin{tabular}{|c|c|c|c|c|c|c|}
\hline & $\mathrm{N}$ & Mean & $\begin{array}{c}\text { Std. } \\
\text { Deviation }\end{array}$ & $\mathrm{df}$ & Sig. (2-tailed) & Remark \\
\hline Urban & 722 & 17.0069 & 2.88930 & 1401 & 043 & Simnificant \\
\hline Rural & 681 & 16.6990 & $2.79582^{2.021}$ & & & \\
\hline
\end{tabular}

The result in Table 7 shows that there is a significant difference in management effectiveness between school governing boards in rural and urban public secondary schools in Oyo State, Nigeria $(\mathrm{p}<0.05)$. The result in Table 7 further reveals that management effectiveness is higher among school governing boards in urban (Mean $=17.0069$ ) public secondary schools in Oyo State, Nigeria than those in the rural region (Mean $=16.6990)$. This implies that the school location with respect to rural and urban has significant effect on the management effectiveness of school governing boards in urban and rural public secondary schools in Oyo State, Nigeria. This concurs with the works of De Grauwe (2008) that a profound difference exists in school systems hence, in the management effectiveness of the school among the school governing boards. Moreover, the location of the school also has significant effect on the school monitoring by school governing boards in rural and urban Public secondary schools in Oyo State, Nigeria.

Hypothesis 2: There is no significant difference in school monitoring between school governing boards of urban and rural public secondary schools in Oyo State, Nigeria. 


\section{Table 8: Independent t-test Comparison of School Monitoring}

\begin{tabular}{|c|c|c|c|c|c|c|}
\hline & $\mathrm{N}$ & Mean & $\begin{array}{c}\text { Std. } \\
\text { Deviation }\end{array}$ & $\mathrm{df}$ & Sig. (2-tailed) & Remark \\
\hline Urban & 704 & 16.5923 & $2.55800_{4.947}$ & 1386 & .000 & Significan \\
\hline Rural & 684 & 15.8772 & $2.82472^{4.94 /}$ & & & \\
\hline
\end{tabular}

The result in Table 8 shows that there is a significant difference in school monitoring between school governing boards in urban and rural public secondary schools in Oyo State, Nigeria $(\mathrm{p}<0.05)$. The result in Table 8 further reveals that school monitoring is higher among school in urban (Mean $=16.5923$ ) public secondary schools in Oyo State, Nigeria than those in the rural region (Mean $=15.8772$ ). This implies that the location of the school has significant effect on the school monitoring by school governing boards in rural and urban public secondary schools in Oyo State, Nigeria. The result of this study is in line with findings of Ekpoh and Bassey (2011) who revealed that school location influences principals' management of indiscipline.

\section{Conclusion}

In conclusion, management effectiveness in the area of human, financial and material resources in public secondary schools in Oyo state was considered to be low. There are adequate and necessary school monitoring process put in place by school monitoring board to ensure management effectiveness in secondary schools in Oyo State, Nigeria. The location of schools has significant effect on the school monitoring and management effectiveness of school governing boards in rural and urban public secondary schools in Oyo State, Nigeria.

\section{Recommendations}

There should be appropriate strategies for effective management to manage the human, financial and material resources in public secondary school system by the school governing boards. There should also be appropriate and continuous school monitoring processes by school governing boards that could help to foster the effective management of available resources towards the attainment of education or schools goals and objectives in the public secondary school system. There should also be the need for equity in attention and the provision and the management of available resources with regards to the effective distribution of these resources to rural and urban schools where necessary school governing boards can make effective uses of them towards achieving the goals and objectives of the education system in Oyo State, Nigeria. 


\section{References}

Achimugu, L. (2005). The agonies of Nigeria teachers. Ibadan: Heinemann Education publishers Limited

Aja, S.N., Eze, P.I. and Nick, E. (2014).Over view of the progress and challenges of education for all in Nigeria, Educational Research57: 257-260.

Ayeni, A. J.(2012).Improving school and community partnership for sustainable quality assurance in secondary schools in Nigeria.International Journal of Research Studies in Education 1.2: 95-102.

Chen G. (2019), Public School vs. Private School, Public School review, https://www.publicschoolreview.com/blog/public-school-vs-private-school

Daily, C. M., D. R. Dalton and A. A. Cannella, Jr (2003), "Corporate governance: decades of dialogue and data”, Academy of Management Review, 28(3): 371-382.

De Grauwe, A. (2008), School Monitoring Systems and their Impact on Disparities, Background paper prepared for the Education for All Global Monitoring Report 2009, Overcoming Inequality: why governance matters, 2009/ED/EFA/MRT/PI/32, UNESCO

Edho, O.G. (2009). The challenges affecting the implementation of the universal basic education (UBE) in Delta State, Nigeria.Journal of Social Sciences20.3: 183-187

Ekpoh, U.I. and Bassey, U. (2011).School Location and Principals' Management of Teachers' Indiscipline in Akwalbom State Secondary Schools, Nigeria.International Journal of Business and Social Science2(6):153-156

Fadipe J.O. (2003). Quality control in education: the teacher factor. In T.E. Ajayi and J. Fadipe(Eds) Skills improvement programme for effective performance of teachers in Nigerian schools. A publication of National Institute for Educational planning and Administration(NIEPA), Ondo, 128-143.

Frame, S. M. (1990). The effect of employment location on perception of teaching competences among first yearteachers. A research report S. P. 032844 of Idaho/Washington School District.

Galetuke, M.T. (2017). School governing bodies' support ofschools to promote quality academicperformance. Unpublished Master Dissertation in Education Managementat the North-West University

Ikgbusi, N. G. and Iheanacho, R. C. (2016), Factors militating against effective administration of secondary. World Journal of Educational Research 3.1. 
Kalagbor, L.D. (2016). An Analysis of Factors Influencing Students' Academic Performance in Public and Private Secondary Schools in Rivers State-Nigeria.Journal of Education and Practice 7 (8):96-101

Kotirde I.Y. and YunosJ.B. (2015). The Processes of Supervisions in Secondary Schools Educational System in Nigeria, 4th World Congress on Technical and Vocational Education and Training (WoCTVET), 5th-6 $6^{\text {th }}$ November 2014, Malaysia, Procedia Social and Behavioural Sciences 204, $259-264$

Marriott, N. and Goyder, H. (2009).Manual for Monitoring and evaluating education Partnership.International Institute for Educational Planning. Paris

Mertens, D. M. (2005). Research and Evaluation in Education and Psychology.Sage Publications. London. 45- 47

Mncube, V., Harber, C. and Du Plessis, P. (2011). Effective school governing bodies: parentalinvolvement. ActaAcademica, 43(3):210-242.

Moja, T. (2000). Nigeria education sector analysis: an analytical synthesis of performance and main issues. New York: World Bank Document.

Nwakpa P. (2017), Management of diversification at the senior secondary education level in Nigeria by the school administrators. Educational Research, International Research journals 8.1.http://www.interesjournals.org/ER

Ogie, L.I. (2015). Influence of principals' management style on secondary school facilities in Rivers State, Nigeria. The International Journal of Humanities and Social Sciences.

Oladeji, O. (2017). Oyo House deliberates on poor performance of students. http://thenewsnigeria.com.ng/2017/08/oyo-house-deliberates-on-poorperformance-of-students/

Omiunu O.G. (2014), Enhancing Human Capital Efficiency in the Nigeria Educational Sector. Journal of Education and Practice5.14: 69-73

Omoregie,N. (2005). Re-packaging secondary education in Nigeria for great and dynamic economy. Paper presented at the $2^{\text {nd }}$ annual National Conference of Association for encouraging Qualitative Education in Nigeria (ASSEQEN). 9th-11th may

Ozkan T. and Tokel A., (2018), Evaluation of the Managerial Effectiveness of School Administrators by the Views of Teachers, EURASIA.Journal of Mathematics, Science and Technology Education 14(5): 2025-2037 
International Journal of Advanced Academic Research (Arts, Humanities and Education) | ISSN: 2488-9849 Vol. 6, Issue 12 (December, 2020) | www.ijaar.org

Journal DOI: 10.46654/ij.24889849

Article DOI: 10.46654/ij.24889849.a61252

Uchendu, C.C. (2011).Human resources management and teachers' job performance for sustainable development of secondary schools in Cross River State. The LEAJON: An Academic Journal of Interdisciplinary Studies 2.2. 